\title{
PENERAPAN ATRAUMATIC CARE TERHADAP RESPON FISIOLOGIS DAN RESPON PSIKOLOGIS YANG MENGALAMI HOSPITALISASI
}

Delfatmawati ${ }^{*}$, Rina Mariyana ${ }^{2}$

1,2ProgramStudi Keperawatana, Universitas Fort De Kock Bukittinggi Email : delfatmawati@gmail.com

Submitted: 11-02-2020, Reviewer: 15-02-2020, Accepted: 15-02-2020

\begin{abstract}
ABSTRAK
Agency for healtcare research and quality and nationwide in patient sampel (2009) menunjukkan anak usia dibawah 17 tahun yang dirawat di rumah sakit America Serikat sebanyak 6,4 juta dan sebanyak $17 \%$ anak cemas dan nyeri saat di rawat di rumah sakit. Kondisi sakit dan masa saat dirawat di Rumah Sakit (menyebabkan stres pada anak maupun orangtua. Atraumatic care atau asuhan yang tidak menimbulkan trauma pada anak da keluarganya merupakan asuhan yang terapeutik karena bertujuan sebagai terapi bagi anak.. Tujuan penelitian ini adalah untuk menerapkan atraumatic care serta mengetahui pengalaman anak terhadap respon fisiologis dan respon psikologis yang mengalami hospitalisasi di Payakumbuh: Mixed Methods Research setelah didapatkan data kualitaif pasien lalu di nilai penerapan atraumatik care nya.. Partisipan dalam penelitian kualitatif menurut berkisar antara 10 30 orang partisipan. Pengambilan partisipan dalam penelitian ini diaw ali dengan purposive sampling. Hasil yang di peroleh terdapat 4 tema respon fisik terdiri dari Fisik Terganggu, Aktifitas Terganggu dan Tema Respon Psikologis yaitu Respon Perilaku, Respon Afektif. Setelah di peroleh data kualitatif di terapkan lah terapi untuk menurunkan respon cemas anak. Penelitian ini diharapkan dapat menerapkan perawatan atraumatic care sesuai standar operasional peraw at pada anak yang mengalami hospitalisasi serta menggambarkan pengalaman anak terhadap respon fisik (nyeri, kelelahan dan gangguan tidur) dan respon psikologis (cemas dan depresi) yang dirasakan agar meningkatkan kualitas kesehatan tanpa adanya gangguan fisik dan psikologis.
\end{abstract}

Keywords/Kata Kunci : Hospitalisasi, Respon Fisiologis, Respon Psikologis, Atraumatic care 


\section{PENDAHULUAN}

Anak memiliki karakter yang unik dan kebutuhan berbeda setiap tahap pertumbuhan dan perkembangannya ${ }^{1}$. Pada fase tumbuh kembang perlu di perhatikan kebutuhan anak agar terhindar dari penyakit ${ }^{2}$. Kondisi sakit dapat menyebabkan stres disebut sebagai masa hospitalisasi. Hospitalisasi anak memiliki persepsi yang berbeda tergantung dari pengalaman anak, usia perkembangan, serta mekanisme koping 3 . Reaksi yang timbul pada anak yaitu kurang mampu memahami situasi, keadaan lingkunga n asing serta perubahan rutinitas di rumah sakit menjadikan hal yang menakutkan pada anak 4 .

Berdasarkan survey kesehatan nasional (Susenas) tahun 2014 didapatkan angka kesakitan anak sebanyak 15,26 \% data per usia di di indonesia usia 0-4 tahun sebesar 29,8 $\%$, usia 5-12 tahun sebesar 10,91\%. Menurut Faozi (2010) sebanyak 69,2 \% anak mengalami hospitalisasi berulang sering dan 30,8 \% hospitalisas i berulang sedang. Dampak yang ditimbulkan menyebabkan penanganan dalam perawatan anak sering kali terhambat. Seing mendapat perlakuan yang tidak menyenangkan saat dirawat sewaktu kecil membuat anak menjadi trauma pada jangka waktu lama ${ }^{5}$. Berdasarkan hal tersebut, perawat diharapkan dapat menciptakan asuhan keperawatan dengan pendekatan atraumatik care.

Atraumatic care adalah tindakan perawat yang bisa membuat anak yang dirawat tidak menyebabkan trauma dan dapat mengurangi stressbaik fisik dan psikologis. Pada penelitian lain yang dilakukan Da Motta (2014) didapatkan hasil pencegahan trauma hospitalisasi dapat dilakukan dengan menerapkan atraumatic care. Penerapan tersebut dilakukan untuk mencegah terjadinya cedera dan nyeri pada anak ${ }^{6}$,

Berbagai upaya telah dilakukan perawatuntuk mengurangi distress fisik maupun psikologis pada anak akibat prosedur. Penerapan penelitian dalam penurunan intensitas nyeri dan rasa takut pada anak selama prosedur telah diupayakan perawat namun di indonesia penerapan atraumatic care perlu ditingkatkan, terutama rumah sakit daerah yang belum memahami pentingnya atraumatic care. Beberapa wawancara kepada perawat penerapan 
atraumatic care belum dirasakan optimal hingga anak cenderung ketakutan saat dirumah sakit

Menurut Tri-Service General Hospital, 2015 \& Da Motta, 2014, telah dilakukan Pencegahan atraumatic care dengan pemberian sukrosa, NNS (Non Nutritive Sucking) dan pemberian asi pada penelitian ini diterapkan pada anak mengalami cemas setelah di berikan pemberian sukrosa dan asi anak mengalami penurunan cemas anak.

Anak yang di Hospitalisasi pasti akan berbeda untuk kemampuan koping nya hal ini banyak faktor yang mempengaruhi nya seperti: Faktor Umur, Faktor pengalaman masa lalu terhadap hospitalisasi, Faktor yang merawat selama sakit, perpisahan ataupun keseriusan penyakit,. Jika selama dalam perawatan anak mengalami cemas dan stress, orang tua juga menjadi mudah stress, hal ini membuat orang tua tingkat stres semakin meningkat dan akan berakibat pada anak. Kecemasan ini ditunjukan dengan cara menolak makan,susah untuk tidur,menangis,sela lu menanyakan orang tua dan menarik diri (Supartini, 2004). Beberapa bukti penelitian menunjukkan bahwa lingkungan rumah sakit yang dapat menimbulkan trauma bagi anak adalah lingkungan di rumah sakit seperti : segi tenaga kesehatan dengan sikap dan tindakan, penampilan pakaian, alat yang digunakan, dan lingkunagan sosial antar sesama pasien. Dengan adanya stresor tersebut, menjadi ancaman dapat dialami anak, pada respon fisik nya seperti gangguan tidur, aktivitas fisik yang dibatasi, nyeri, , sedangkan untuk respon psikologis mencakup kecemasan, takut, marah, kecewa, sedih, malu, dan rasa bersalah (Supartini, 2004).

\section{Data RSUD Adnan WD} Payakumbuh pada Bulan Januari Desember 2016 didapatkan sebanyak 509 anak kurang kooperatif dari 894 anak yang dirawat. Sementara di tahun 2017 didapatkan 45\% anak tidak kooperatif saat dilakukan tindakan. Oleh karena itu perlu digali respon fisik dan psikologis yang ditimbulkan anak saat mengalami hospitalisasi untuk diterapkannya atraumatic care di Rumah Sakit Adnan WD Payakumbuh : Mixed Methods ResearchI tujuan dilakukan penelitian ini supaya perawat memperhatikan respon yang di 
timbulkan anak saat di rawat supaya anak tidak mengalami trauma

\section{METODE PENELITIAN}

Penelitian ini menggunakan metode mixed methods yang merupakan suatu langkah penelitian yang mengkombinasi metode penelitian antara metode kuantitatif dengan metode kualitatif untuk digunakan secara bersama - sama dalam suatu kegiatan penelitian, sehingga diperoleh data yang lebih komprehensif, valid, reliabel dan obyektif. Sampel yang digunakan sebanyak 30 otang dilakukan di ruang rawat anak RSUD Dr adnand WD payakumbuh, pengumpulan data dengan kriteria inklusi anak yang mengalami kecemasan saat di rawat dan kriteria eksklusi pada anak yang mengalami kejang dan koma tidak di ambil datanya.

\section{HASIL DAN PEMBAHASAN}

Penelitian ini menggunakan metode gabungan (mixed methods) dimana data yang diperoleh berupa data kualitatif dan data kuantitatif. Bagian ini menjelaskan tentang hasil penelitian yang telah dilakukan yang bertujuan untuk mengetahui pengaruh penerapan atraumatik care terhadap respon fisiologi dan respon psikologis pada anak dengan hospitalisasi di Rumah Sakit.

\section{a. Hasil Kualitatif}

Proses analisis data pada penelitian kualitatif dilakukan secara simultan dengan proses pengumpulan data. Data yang diperoleh melalui wawancara, observasi partisipan yang ditulis dalam bentuk transkrip. Transkrip data kemudian dianalisis dengan cara melakukan koding yaitu menyusun secara sistematis data yang ditemukan secara lengkap dan rinci sehingga menghasilkan gambaran tentang fenomena yang diteliti.

Hasil dari proses analisa data telah menemukan 4 tema dari respon fisiologi dan respon psikologis. Tema respon fisik terdiri dari Fisik Terganggu, Aktifitas Terganggu dan Tema Respon Psikologis yaitu Respon Perilaku, Respon Afektif. Setelah di peroleh data kualitatif di terapkan lah terapi untuk menurunkan respon cemas anak.

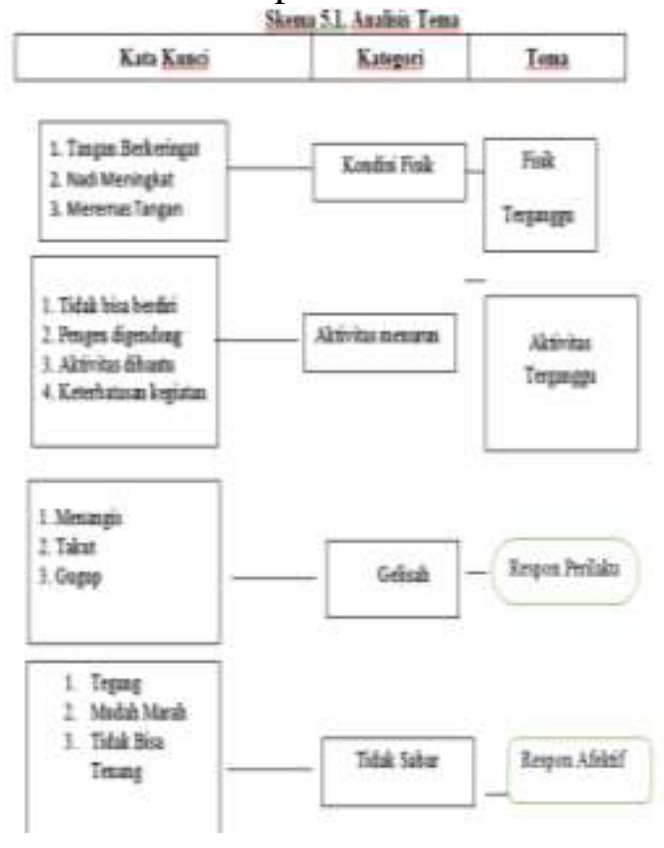

Tema 1: Fisik Terganggu

Anak yang Dirawat di rumah sakit Mengalami Gangguan Fisik. Adapun Kondis Fisik yang terganggu seperti Tangan berkeringat, Nadi Meningkat, Meremas Tangan.

Seperti ungkapan beberapa responden berikut :

".....pas di pasang infus wak pacik tangannyo bakaringek....(P9)”.

“......wakatu jarum ka ditusuak katangan nyo dipegang tangannyo dingin taraso .....(P17)". 
"...apo se nan di karajoan perawat garik nyo di rameh nyo tangan nyo ....(P21)"

Tema 2 : Aktivitas Menurun

Aktivitas anak saat mengalami hospitalisasi Mengalami : tidak bisa berdiri, pengen digendong aktivitas dibantu, Keterbatasan kegiatan.

Beberapa partisipan mengungkapkan hal tersebut berikut ini:

“.....yo salamo ko biasonyo lalok saja di ruang ko....(Pl)”

“.....apak kini ndak ado bana karajo yang barek lai, sekedar mambarasihan halaman sajo...(P2)"

"......kalau sekarang aktivitas ibuk seperti biasa aja, cuma memang keluarga melarang ibuk bekerja keras, ndak boleh gitu ya, terus tapi ibuk merasa badan ibuk sudah mulai biasa aja ...(P3)”.

Tema : 3 Respon Perilaku

Anak Yang dirawat Mengalami perubahan pada respon perilakunya antara lain: Menangis, Takut, Cemas. Beberapa Partisipan Mengungkapakan :

“..... pas masuak Rs Ko manangih nyo, apalagi kalau nio disuntik ubek lewat infus. Alah takutnyo ndak nio disuntik. (P3)”'

“...... inyo alah 2 hari dirawat masih cengeng juo..biasonyao lai ndak rewel buk..takut mungkin disiko.....(P4)

"...... dedek karena angek bana buk makonya managih sajo dari tadi malam.. tapi apalgi kalau nio disuntikan ubek.. alah paniang mamegannngnyo. ( P7)

Tema 4 : Respon Afektif

Dismaping perubahan respon perilaku Anak yang dirawat di rawat dirumah sakit juga mengalami perubahan pada respon Afektif nya seperti tidak sabar, tidak tenang. marah
Hal ini ditunjukan dengan Beberapa Partisipan mengungkapkan :

“......anakko indak amuah tanang sajo bu.. minta bawo kalua sudah tu minta jalanjalan manunjuk kalua. Padahal infus sdg tapasang. ( P 17)

“...... ondeh buk..berang nyo bu..ka awak..ditulaknyao tangan perawat karena takut ka disuntik .. itu sajonyo buk kalau ndak suko ( p6)

“........kadang lai sabarnyo buk.pas awal dirawat kurang sabar buk... (p12)

\section{Riset kuantitatif}

Penerapan Atraumatic Care Dengan Kecemasan Pada Anak Yang mengalami Hospitalisasi Di RSUD Adnaan WD.Payakumbuh Tahun 2019

Tabel 2.1

Distribusi Frekuensi Atraumatic care pada Anak Yang mengalami Hospitalis asi Di RSUD Addnaan WD Payakumbuh Tahun 2019

\begin{tabular}{llll} 
No & Atraumatic Care & f & $\%$ \\
\hline & & & \\
\hline 1. & Baik & 13 & 43,3 \\
\hline 2. & Tidak Baik & 17 & 56.7 \\
\hline & Jumlah & 30 & 100
\end{tabular}

Tabel 2.1 menunjukan bahwa dari 30 responden, terdapat lebih dari sebagian yaitu sebanyak 17 orang $(56,7 \%)$ responden dengan penerapan atraumatic care kurang baik.

Tabel 2.2

Distribusi Frekuensi Kecemasan pada Anak Yang mengalamiHospitalisasi Di RSUD Addnaan WD Payakumbuh Tahun 2019 


\begin{tabular}{cccc} 
No. Kecemasan & $\mathrm{f}$ & $\%$ \\
\hline \multicolumn{5}{c}{ Ringan } & 12 & 42.9 \\
\hline 2. & Sedang & 18 & 58,1 \\
\hline \multicolumn{5}{c}{ Jumlah } & 30 & 100
\end{tabular}

Tabel 2.2 menunjukan bahwa dari 30 responden, terdapat lebih dari sebagian yaitu sebanyak 18 orang $(58,1 \%)$ responden dengan cemas sedang

\section{PEMBAHASAN}

Berdasarkan hasil penelitian menunjukkan bahwa dari 30 responden, terdapat sebanyak 17 orang $(56,7 \%)$ responden dengan penerapan atraumatic care kurang baik.

Penerapan Atraumatic care adalah pelayanan kesehatan pada anak yang sakit namun tidak menimbulkan stress fisik dan psikologis yang dialami anak maupun orangtua[6].

Atraumatic care dalam pencegahannya fokus pada trauma akibat dari tindakan keperawatan pada anak. Berdasarkan penelitian Lory Huff et al., menyatakan bahwa penerapan Atraumatic Care pada anak yang dirawat di rumah sakit dapat menurunkan trauma pada anak dan orang tua akibat prosedur invasif.dan dapat meminimalkan kesemasan. [4].

Berdasarkan hasil penelitian, yaitu sebanyak 18 orang $(58,1 \%)$ responden dengan cemas sedang.

Kecemasan merupakan perasaan yang dialami pada saat Hospitalisasi sesuai dengan pemahaman dan pemikiran mereka sehingga menimbulkan stresor baik pada saat masuk rumah sakit untuk pertama kalinya atau selama selama proses rawatan [1].
Kecemasan setiap anak tergantung pada faktor umur dan perkembangannnya, pengalaman rawatan sebelumnya terhadap sakit, serta dukungan yanga ada sehinnga kecemasan anak pasti akan berbeda setiap individunya.

Penelitian ini sejalan dengan Muzakki (2006) bahwa klien dengan tingkat kecemasan sedang sering ditanggulangi degan pemeriksaan yang serius sedangkan kecemasan ringan untuk pemeriksaan yang sifatnya tidak begitu serius, dimana perawat dan orang tua dapat memberikan lingkungan yang aman dan nyaman kepada anak agar anak tidak merasa cemas ketika sedang dirawat di rumah sakit. Menurut (Wong 2009) kecemasan anak juga sering kali dihadapakan dengan prosedur yang menimbulkan nyeri, kehilagan kemandirian, dan berbagai hal yang tidak diketahui. [2].

Menurut asumsi peneliti ketakutan dan kecemasan yang anak - anak alami saat di rawat di RS adnaan WD banyak terjadi karena adanya perpedaan lingkungan dari yang biasa ramai menjadi sepi bahkan tidak adanya teman bermain seperti dirumah disamping itu, perlakuan dalam pemberian pelayanan oleh perawat seperti tindakan menginfus, mengukur suhu, dan memeberi obat injeksi maupun oral juga memberikan efek rasa takut pada mereka.

Anak yang di Hospitalisasi di Ruang rawat Rs.Adnaan WD dengan tingkat kecemasan sedang.

Carson dalam Wong (2003) menjelaskan bahwa untuk anak yang mengalami hospitalisasi membagi mereka pada tingkat cemas sedang dan berat.

Sehingga wajar jika hal ini terjadi karena anak-anak masih mempunyai pengetahuan yang belum menyeluruh tentang proses perawatan dengan baik, tetapi dengan 
penjelasan yang sederhana dan kasih sayang oleh orang tua seperti melaksanakan penerapkan atraumatic care seperti orang tua mengatur lingkungan agar anak merasa nyaman dengan cara pelukan, sentuhan, memberikan hiburan pada anak dengan mengajak anak bermain dan bernyanyi sambil bersalawat agar anak bisa tenang dan

\section{SIMPULAN}

Berdasarkan hasil dan pembahasan tentang penerapan atraumatic care terhadap respon fisik dan psikologis yang timbul saat anak mengalami hospitalisasi di rumah sakit Adnaan WD payakumbuh dapat disimpulkan penerapan Atarumatic care di rumah sakit Adnaan WD payakumbuh termasuk dalam katagori belum baik oleh orang tua $(57,7 \%)$ dan mayoritas anak didapatkan mengalami kecemasan $(58,1) \%$ saat proses hospitalisasi di RS Adnaan WD Payakumbuh. Sedangkan pada respon fisiologis anak anak yang di hospitalisasidi RS Adnaan WD Payakumbuh mengalami fisik yang terganggu dan aktifitas yang terganggu. Begitu juga dengan respon psikologis anak mengalami Respon Afektif dan Perilaku.

\section{UCAPAN TERIMAKASIH}

Kami mengucapkan terimakasih kepada pihak RSUD payakumbuh karena telah memfasilitasi kami dalam melakukan penelitian dan kepada orang ttua anak yang bersedia untuk diwawancara, terimakasih kepada tim jurnal kami ucapkan atas kesempatan kami untuk publish disini

\section{DAFTAR PUSTAKA}

Utami, Resti. Hubungan Penerapan Atraumatic Care Dengan Tingkat Kepuasan Orang Tua Anak Selama Proses Hospitalisasi di Ruang Anak Rumah Sakit Daerah Balung Jember. Skripsi. Jember: ProgramStudi Ilmu Keperawatan Universitas Jember. 2012. [1] dapat mengerti, memahami perawataan yang dilakukan adalah demi kesehatannya. Bahkan ada orang tua juga menjanjikan sesuatu yang anak minta saat dirawat dan jika mereka pulang kerumah nanti akan ditepati, sehingga anak - anak merasa termotivasi dan menurut selama pengotan di rumah sakit.

Wong, Donna L. Buku Ajar Keperawatan Pediatrik.Jakarta: EGC. 2009 [2]

Jetten, A. M. recent advances in the machanisms ofaction and physiological fungtions of the retinoid-releted orphan receptors (RORs)[internet]. 2004. [3]

L. Huff et al. Atraumatic Care: Emla Cream andApplication of Heat to Facilitate Peripheral VenousCannulation In Children [internet]. 2009. [4]

Hubungan penerapan Atraumatic care dengan TingkatKecemasan Anak Prasekolah Saat Proses Hospitalisasi di RSU dr. H. Koesnadi Kabupaten [5]

Hubungan Penerapan Atraumatic Care dengan TingkatKecemasan Anak Prasekolah Saat Proses HospitalisasiHasil korelasi hubungan antara penerapan Atraumaticcare dengan kecemasan anak prasekolah [6]

Beevi, A. (2009). Textbook of pediatric nursing. Kundli : Sanat Printers. Didapatkan dari

https://books.google.co.id/books?id=IoQmA xKE_WOC\&pg=PA10\&dq=atraumatic+care + is\&hl=en\&sa $=X \&$ redir_esc $=y \# \mathrm{v}=$ onepage $\& \mathrm{q}=$ atraumatic $\% 20 \mathrm{care} \% 20 \mathrm{is} \& \mathrm{f}=$ false

Beevi, A. Textbook of pediatric nursing. Kundli : Sanat Printers.

Bowden, V.R. \& Greenberg, C.S. (2010). Children and their families : The Continuum of Care. (2nd ed.). Philadelphia : Lippinc ot Williams \& Wilkins 
Breving, R.M., Ismanto, A.Y., Onibala, F. (2015). Pengaruh penerapan atraumatic care terhadap respon kecemasan anak yang mengalami hospitalisasi di RSU Pancaran Kasih GMIM Manado dan RSUP Prof. Dr. R.D. Kandou Manado. e-Journal Keperawatan,3(2), pp 1-9

Cahyaningrum, D.S. (2011). Pertumbuhan perkembangan anak dan remaja. Jakarta : CV. Trans Info Media

Coyne, I. (2006). Children experiences of hospitalization. Journal of Child Health Care., 10 (4) 326-336

Coyne, I., O’Neill, C., Murphy, M., Costello, T.,\& O'Shea, R. (2011). What does familycentred care mean to nurses and how do they think it could be enhanced in practice. Journal Of Advanced Nursing;67(12):2561-2573

Da Motta, G. (2014). Revista Brasileira de Enfermagem. Prevention and nonpharmacological management of pain in newborns. Diperoleh dari http://remotelib.ui.ac.id:2073/docview/1682191500/3ED 94F6AC4164263PQ/2? accountid=17242

Fletcher, K, E. (2003). Child Psychopathology. 2 ed. New York: the Guilford Press.

Harrison D, Beggs S, Stevens B. (2012). Sucrose for procedural pain management in infants. Pediatrics.;130(5):918-25.

Hockenberry, M. J., Wilson, D., \& Wong, D. L. (2007). Wong's Nursing Care of Infants And Children. Eight edition.St. Louis: Missouri.
Hidayat, A.A.A. (2005). Pengantar ilmu keperawatan anak I. Jakarta : Salemba Medika

Hockenberry, J.M., \& Wilson, D. (2009). Essentials of pediatric nursing. St. Louis : Mosby An Affilite of Elsevier inc.

Hensel, D., Morson, G. L. \& Preuss, E. A. (2013). Best practice in newborn injections. The American Journal of Maternal/ Child Nursing. 38 (3), p. 163-167.

Jalal, Fasli. (2002). Pendidikan, Input Tumbuh Kembang Anak. (online)(http://www.pik0902/09/teropong/lai

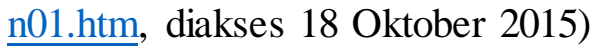

Jose, J. \& Umarani J. (2013). Effect of ice application in reducing pain perception of toddlers during immunization. International Journal of Recent Scientific Research. 4(5), p. 630-633.

Liaw JJ, Zeng WP, Yang L, Yuh YS, Yin T, Yang MH. (2011). Nonnutritive sucking and oral sucrose relieve neonatal pain during intramuscular injection of hepatitis vaccine. J Pain Symptom Manage [Internet]. [cited 2015 October 15];42(6):918-30. Available from: http://www.ncbi.nlm. nih.gov/pubmed/21620644

Liaw JJ, Yang L, Katherine Wang KW, Chen CM, Chang YC, Yin T. (2012). Non-nutritive sucking and facilitated tucking relieve preterm infant pain during heel-stick procedures: a prospective, randomised controlled crossover trial. Int J Nurs Stud [Internet]. [cited 2015 October 15];49(3):300-9. Available from: http://www.ncbi.nlm. nih.gov/pubmed/22001561 
Muscari, M. E.(2005). Keperawatan

Pediatrik. Edisi 3: jakarta :EGC

Obeidat H, Kahalaf I, Callister LC, Froelicher ES. (2009). Use of facilitated tucking for nonpharmacological pain management in preterm infants: A systematic review. J Perinat Neonatal Nurs [Internet].[cited 2015 October 15];23(4):3727. Available from: http://www.ncbi.nlm. nih.gov/pubmed/19915422

Roohafza. H., pirnia, A., Sadeghi, M., Toghianifar, n., Talaei, $\mathrm{M} \&$ ashrafi, $\mathrm{M}$ (2009). Impact of nurses clothing on anxiety of hospitalised childern. Journal of Clinical Nursing, 18, 1953-1959 